\title{
Distribution of Sri Lanka Dull-blue Flycatcher (Eumyias sordidus) in the Horton Plains National Park
}

\author{
Dharmarathne WDSC and Mahaulpatha WAD
}

Department of Zoology, Faculty of Applied Sciences, University of Sri Jayewardenepura, Sri Lanka

\begin{abstract}
Distribution of the Sri Lanka Dull-blue Flycatcher (Eumyias sordidus) was studied at Horton Plains National Park, from September 2015 to May 2016. Three main habitats were identified as Cloud Forest habitat, Cloud Forest Die-back habitat and Grassland habitat. Line transact method was used. Birds were recorded on three consecutive days in each month while travelling along these transacts. About 104 individuals were recorded from the Cloud Forest habitat, 60 individuals from the Cloud Forest Die-back habitat and 2 individuals were recorded from the Grassland habitat. Relative abundance of the E. sordidus was $2.3 \%$ in the cloud Forest habitat and they were the ninth abundant species in that habitat. In the Cloud Forest Die-back habitat relative abundance of E. sordidus was $3.21 \%$ and it was the sixth abundant species. In the Grassland habitat the relative abundance of $E$. sordidus was $0.07 \%$ and it was twenty seventh abundant species. Present study revealed that Cloud Forest is the preferred habitat of E. sordidus in the Horton Plains National Park.
\end{abstract}

KEYWORDS: Sri Lanka Dull-blue Flycatcher, endemic birds, Horton Plains, distribution

Corresponding author: W. A. D. Mahaulpatha, Email: mahaulpatha@sjp.ac.Ik 


\section{INTRODUCTION}

It has been observed that rate of extinction among species confined to small islands are increasing (Bird life international 2012). This loss is largely due to their increasingly intolerance to the slightest ecosystem disturbances (Nsor \& Obodai, 2014) and the fact that specialization to any one environment may limit a species ability to exploit multiple environments and have a wide range (Futuyma $\&$ Moreno, 1988). Therefore, it is very important to conduct research on the ecology of endemic bird species confined to specific areas to identify appropriate conservation methods.

\section{LITERATURE SURVEY}

Sri Lanka is a humid tropical island lying in the South Asian region, southwest of the Indian peninsula, in the Indian Ocean. Sri Lanka is, together with the Western Ghats of India considered as a global Biodiversity Hotspot (Myers et al., 2000). Sri Lanka Dull-blue flycatcher, Eumyias sordidus, (Figure.1) also known as the Dusky-blue flycatcher, is a small passerine bird in the flycatcher family Muscicapidae (Walden, 1870).

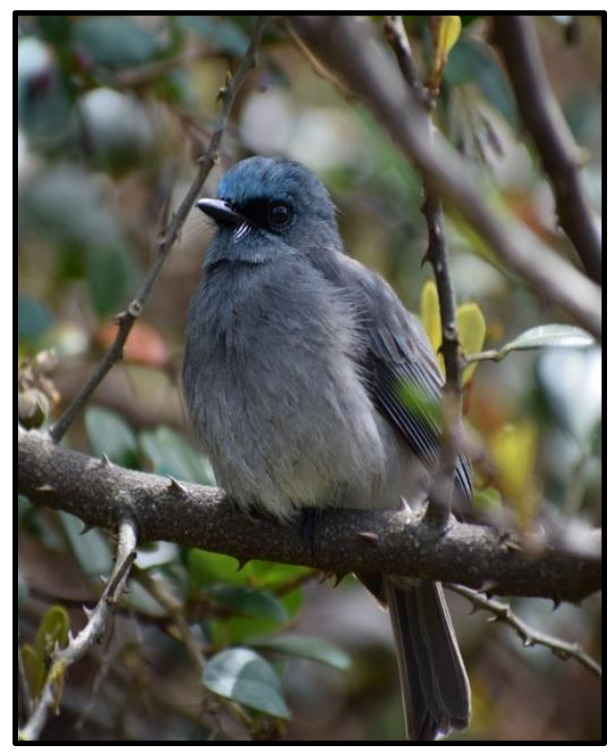

Figure 1. Sri Lanka Dull-blue flycatcher.
It is an endemic resident species described as abundant in the central provinces of Sri Lanka (Del Hoyo et al., 2005). It is considered as Near Threatened species (Birdlife International, 2014). The present study was conducted with the aim of identifying the distribution of E. sordidus in the habitats available to it at the Horton Plains National Park.

\section{STUDY SITE}

The study was conducted in the Horton Plains National Park (HPNP) located at $6^{\circ} 47^{\prime}-6^{\circ} 50^{\prime} \mathrm{N}$, $80^{\circ} 46^{\prime}-80^{\circ} 50^{\prime} \mathrm{E}$ (Green, 1990). The HPNP occupies an area of 3,160 ha and is contiguous with Peak Wilderness Sanctuary to the west. It is in the Nuwara Eliya District at the eastern extremity, from September 2015 to to May 2016, West end of the HPNP plateau is dominated by Kirigalpotta $(2,390 \mathrm{~m})$ and northern end is dominated by Totupola Kanda $(2,357 \mathrm{~m})$, respectively second and third highest peaks in the country. Tropical montane cloud forests and wet pathana grasslands are the two distinct habitats in the park (Gunatilleke \& Gunatilleke, 1990) with a narrow ecotone belt of shrubs and herbs between the two. Forest and patana form a mosaic, with a tendency for forests to be confined to the hilltops, mid or upper slopes, and for the grasslands and dwarf bamboo to be on the lower slopes and in the valleys (DWC, 2007).

Its mean annual temperature is $15 \mathrm{C} 0$ and mean annual rainfall is $2150 \mathrm{~mm}$ (DWC, 2007). The weather is dominated by persistent cloud cover and strong winds, sometimes gale-force, during the south-west monsoon (Bastable \& Gunawardena, 1996). The driest months are January and February, when temperatures may reach $27 \mathrm{C} 0$. Wetland habitats occur in the waterlogged depressions in the valleys and surrounding smaller streams. Extensive areas of the montane forest have suffered from canopy die-back, the cause of which is uncertain but may be related to water stress or air pollution. The area of forest die-back, first observed in the 
1960s, had increased from 87 ha $(2.7 \%$ of the National Park) in 1967 to 956 ha $(30.7 \%)$ by 1998 (DWC, 2005).

\section{METHODOLOGY}

Three main habitats in the HPNP were identified as Cloud Forest habitat, Cloud Forest Die-back habitat and Grassland habitat. Three, $300 \mathrm{~m}$ fixed line transacts were marked in each of these habitats using a Global Positioning System device (GPS). Birds were recorded on three consecutive days in each month while travelling along these transacts, from $0530 \mathrm{~h}$ to $1030 \mathrm{~h}$. Birds were observed through a 10x50 binocular. Opportunistic data and incidental observations were used to supplement the population estimates. Relative abundance of birds were calculated to determine population abundance within habitats using the equation, Relative abundance $=$ Number of individuals of a species/Total number of individuals. Microsoft Excel $^{\mathrm{TM}}$ and Minitab $14^{\mathrm{TM}}$ were used to analyze the data.

\section{RESULTS AND DISCUSSION}

Total of 166, E. sordidus individuals were recorded during the study period. Significantly higher number of E. sordidus individuals were observed from the cloud forest habitat $(n=104$, $62.65 \%$ ) and it was comparatively low in the cloud forest die back habitat $(n=60,36.14 \%)$. The lowest number of individuals were observed in the grass land habitat $(\mathrm{n}=2,1.2 \%)$. (Figure.2).

In the cloud forest habitat, the highest number of 27 E. sordidus was recorded in the month of May 2016 and the lowest of 1 was recorded in December 2015. In the cloud forest dieback habitat the highest number of 17 individuals were recorded in the month of February 2016 and none were recorded in October and December 2015. Single individuals were recorded in March and April of 2016 in the grass land habitat (Figure3).

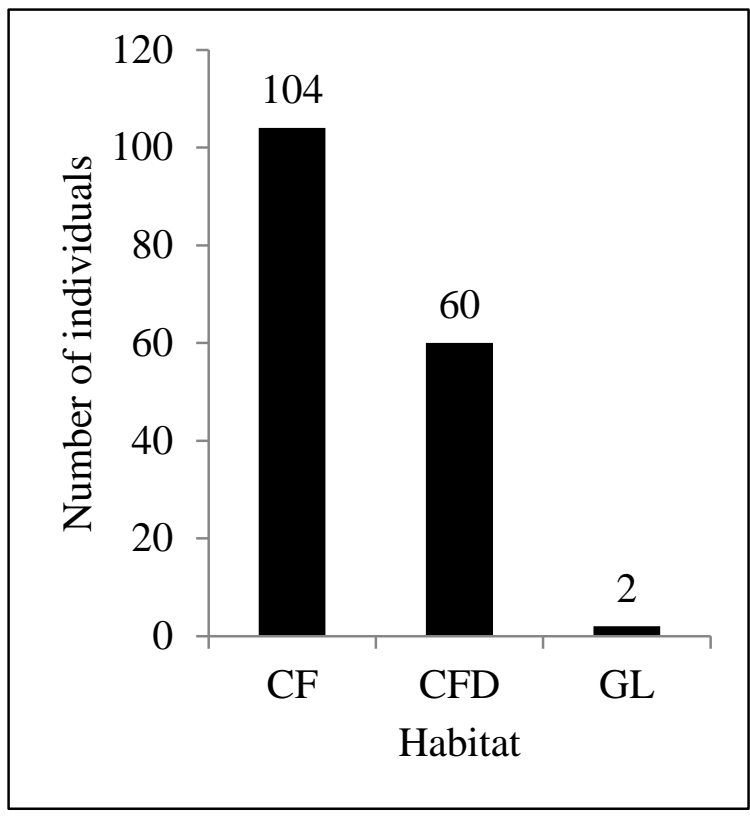

Figure 2. Distribution of E. sordidus in different habitats of the Horton Plains National Park. $\mathrm{CF}=$ Cloud Forest, $\mathrm{CFD}=\mathrm{Cloud}$ Forest Dieback habitat, GL=Grass Land.

Total of 60 bird species were recorded in the cloud forest during the study period and a total of 45 bird species were recorded in the cloud forest dieback habitat. Total of 41 bird species were recorded in the grass land habitat.

Relative abundance of the E. sordidus was $2.3 \%$ in the cloud forest habitat and they were the ninth abundant species in that habitat. In the cloud forest dieback habitat the relative abundance of this species was $3.21 \%$ and it was the sixth abundant species. In the grass land habitat the relative abundance of $E$. sordidus was $0.07 \%$ and it was twenty seventh abundant species.

In the present study highest number of $E$. sordidus were recorded in the cloud forest habitat. The cloud forest habitat had a canopy cover of $81 \% \pm 13 \%(\mathrm{M} \pm \mathrm{SD})$. Therefore, it is evident that the habitat characteristics such as canopy cover influences the habitat selection of E. sordidus. Present study also revealed that in the Horton Plains National Park, the preferred 
habitat of E. sordidus is the cloud forest habitat. Only two individuals were recorded in the grasslands where not have any canopy cover. Although there were scattered trees of Rhododendron arboreum in the grassland habitat they did not provide a suitable canopy. Therefore, the lack of the canopy cover may have prevented E. sordidus from using this habitat. Compared to the grassland habitat the cloud forest die back habit too had a considerable canopy cover. However, due to the forest die back the canopy was not continuous, which may have forced $E$. sordidus to use it at a lesser rate compared to the cloud forest habitat.

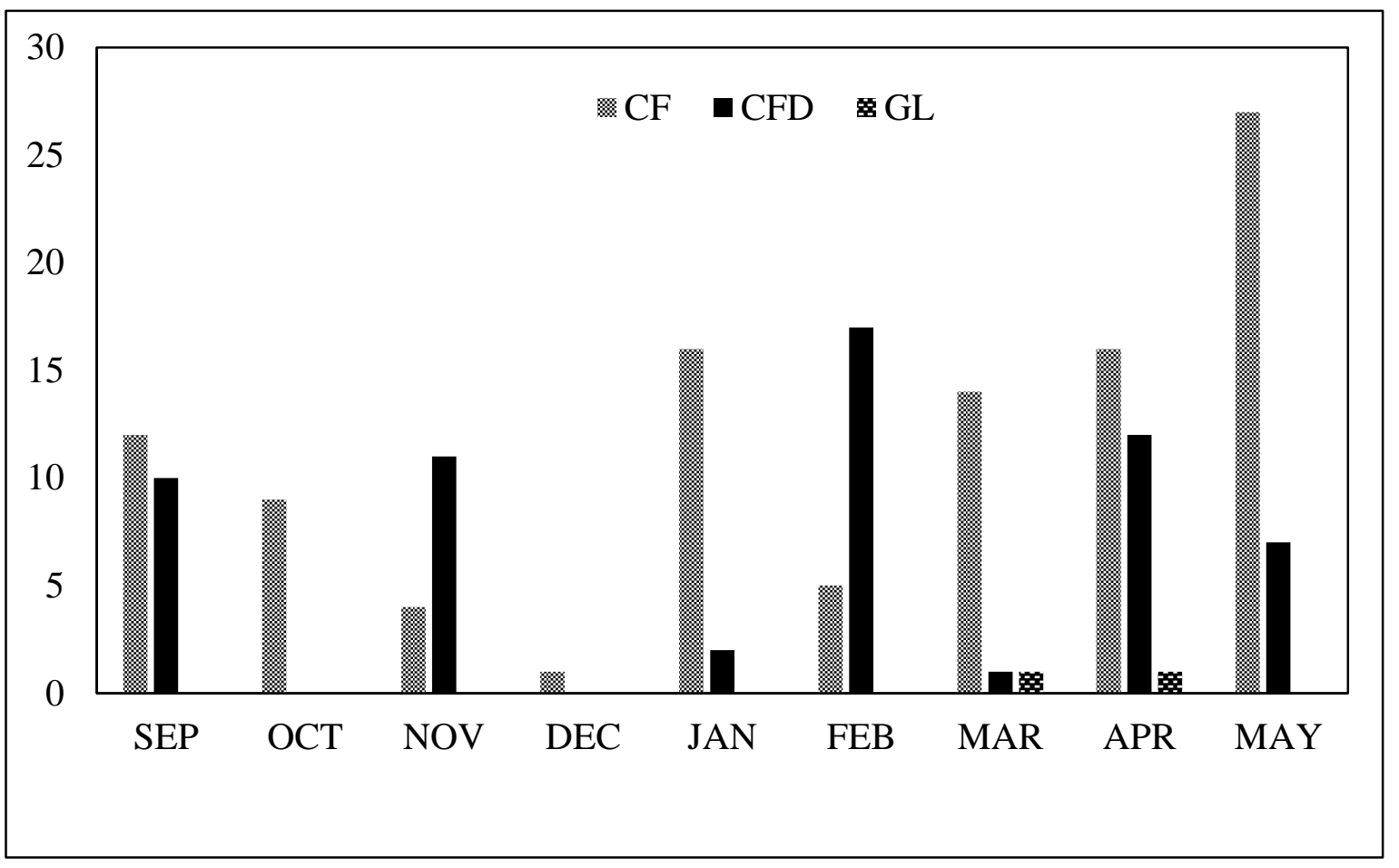

Figure 3. Monthly abundance of E. sordidus individuals during the study period at HPNP.

Previous studies have revealed that the breeding season of E. sordidus is in the first half of the year, March and April being the preferred months (Henry, 1998). The findings of the present study tallied with that of Henry (1998). About $72 \%$ of E. sordidus was observed in the first few months of the year from January to May. Only 28\% was recorded from September to December. Present study revealed that grasslands were occupied by E. sordidus only during the months of March and April. These few birds could be either juveniles exploring the habitat, stragglers or adults collecting nesting materials or food items for feed nestlings and fledglings.
Total of 60 bird species recorded in the cloud forest during the study period indicates that it is the preferable habitat of most of the birds occupying the Horton Plains National Park. Approximately 45 bird species recorded in the cloud forest dieback habitat and the 41 bird species recorded in the grass land habitat clearly indicates that these habitats too are preferable habitats of various bird species.

However for E. sordidus the preferred habitat was the cloud forest. Even then the relative abundance of $2.3 \%$ of E. sordidus in the cloud forest habitat indicates that it is a rather rare bird species and was the ninth abundant species in 
that habitat. In the cloud forest dieback habitat relative abundance of this species was $3.21 \%$ and it was the sixth abundant species. In the grass land habitat the relative abundance of $E$. sordidus was $0.07 \%$ and it was twenty seventh abundant species. This meant that the grass land habitat is its least preferred habitat.

Previous studies, have indicated that species with the smallest geographical ranges, such as those found on mountains or islands (Orme et al., 2006) are the most threatened with extinction (Brooks et al., 1999: Renjifo et al., 1997), and will be more severely affected by climate change (Shoo et al., 2005, White \& Bennett, 2015).

Remnant populations of birds, for instance, are often restricted to mountain ranges (Channell \& Lomolino, 2000) and Limited elevation range increases extinction risk (White \& Bennett, 2015: Manne \& Pimm., 2001). Species with narrow elevation ranges are also more sensitive to land cover change and will be severely affected by climate change (Sorte \& Jetz., 2010).

\section{CONCLUSION}

It is well known that $E$. sordidus prefers wooded highland areas. Therefore, the conservation of montane forests along elevation ranges is essential for present and future species conservation of endemic montane birds including $E$. sordidus. It is equally important that cloud forests of the Horton Plains National Park are preserved to ensure the continuous survival of this elegant bird species.

\section{ACKNOWLEDGEMENT}

We would like to thank the University of Sri Jayewardenepura for the financial support through the university grant (ASP/01/RE/SCI/2016/20). We extend our gratitude to the Department of Wildlife Conservation for granting permission to carry out this study (permit no. WL/3/2/14/15).

\section{REFERENCES}

BASTABLE HG \& GUNAWARDENA ERN. A comparison of climate between two sites at different elevations in Sri Lanka. In Proceedings of the University of Peradeniya/Oxford Forestry Institute Workshop. 1996; 205-220.

BIRDLIFE INTERNATIONAL. Endemic Bird Area factsheet: Sri Lanka. 2014. Available in http://www.birdlife.org. Accessed on $14^{\text {th }}$ of November 2014.

BIRDLIFE INTERNATIONAL. Eumyias sordidus. The IUCN Red List of Threatened Species 2012: e.T22709433A39831282. 2012. Available in http://dx.doi.org/10.2305/IUCN.UK.20121.RLTS.T22709433A39831282.en. Accessed on $25^{\text {th }}$ of March 2016.

BROOKS TM, PIMM SL, KAPOS V \& RAVILIOUS C. Threat from deforestation to montane and lowland birds and mammals in insular South-east Asia. Journal of Animal Ecology. 1999; 68(6): 1061-1078.

CHANNELL R \& LOMOLINO MV. Dynamic biogeography and conservation of endangered species. Nature. 2000; 403(6765): 84-86.

DEL HOYO J, ELLIOTT A \& CHRISTIE D. Handbook of the Birds of the World. Cuckooshrikes to Thrushes. Lynx Editions, Barcelona, Spain. 2005; vol 10.

DWC. Horton Plains National Park. Management Plan. Final Draft. Protected Areas Management and Wildlife Conservation Project, Department of Wildlife Conservation, Colombo. 2005; 91.

DWC. Biodiversity Baseline Survey: Horton Plains National Park. Consultancy Services. Sri Lanka Protected Areas Management and Wildlife Conservation Project (PAM\&WCP/CONSULT/02/BDBS), Department of Wildlife Conservation, Ministry 
of Environment and Natural Resources, Colombo 2007; 40.

FUTUYMA DJ \& MORENO G. The evolution of ecological specialization. Annual Review of Ecology and Systematics. 1998; 19(1):207-233.

GREEN MJB. IUCN directory of South Asian protected areas. ed.IUCN. 1990.

GUNATILLEKE CVS \& GUNATILLEKE IAUN. Horton Plains-Aspect of the vegetation and ecology. Vidurava, 1990; 123: 4-12.

GUNATILLEKE $\mathrm{N}$ \& PETHIYAGODA R. Grasslands. Horton plains: Sri Lanka's cloudforest national park. Wildlife Heritage Trust, Sri Lanka.2012; 141-168.

HENRY GM. A Guide to the Birds of Ceylon. 3rd ed, Oxford university press, London. 1998.

LA SORTE FA \& JETZ W. Projected range contractions of montane biodiversity under global warming. Proceedings of the Royal Society of London B: Biological Sciences. 2010; p.rspb20100612.

MANNE LL \& PIMM SL. Beyond eight forms of rarity: which species are threatened and which will be next? Animal Conservation. 2001; 4(3):221-229.

MYERS N, MITTERMEIER RA, MITTERMEIER CG, DA FONSECA GA \& KENT J. Biodiversity hotspots for conservation priorities. Nature. 2000; 403(6772):853-858.

NSOR CA \& OBODAI EA. Environmental determinants influencing seasonal variations of bird diversity and abundance in wetlands, Northern Region (Ghana). International Journal of Zoology. 2014.

ORME CDL, DAVIES RG, OLSON VA, THOMAS GH, DING TS, RASMUSSEN PC, RIDGELY RS, STATTERSFIELD AJ, BENNETT PM, OWENS IP \& BLACKBURN
TM. Global patterns of geographic range size in birds. PLoS Biol, 2016; 4(7):208.

RENJIFO LM, SERVAT GP, GOERCK JM, LOISELLE BA \& BLAKE JG. Patterns of species composition and endemism in the northern Neotropics: a case for conservation of montane avifaunas. Ornithological Monographs.1997; 577-594.

SHOO LP, WILLIAMS SE \& HERO JM. Climate warming and the rainforest birds of the Australian Wet Tropics: Using abundance data as a sensitive predictor of change in total population size. Biological Conservation. 2005; 125(3):335-343.

WHITE RL \& BENNETT PM. Elevational distribution and extinction risk in birds. PloS one. $2015 ; 10(4): \mathrm{e} 0121849$. 